\title{
Effect of Table Tennis Training on Reaction Times of Down-syndrome Children
}

\author{
Mehmet Ilkim, Betül Akyol* \\ Faculty of Sport Sciences, İnönü University, Turkey
}

Copyright $(\mathrm{O} 2018$ by authors, all rights reserved. Authors agree that this article remains permanently open access under the terms of the Creative Commons Attribution License 4.0 International License

\begin{abstract}
The purpose of this study was to assess the reaction times of individuals with Down syndrome, aged 12-15 participated in table tennis exercise for 12 weeks. Twenty children with Down syndrome participated in the project "Every child succeeds if you give a chance" that the governor of Malatya started to work. Ten children with down syndrome voluntarily participated in the exercise group. Ten children with Down's syndrome were included different study and were evaluated as a control group. Children in exercise group and control group participated in the study were regularly trained 90 minutes three days a week by expert table tennis coaches. In the training sessions, ball throwing with racket, ball throwing on a wall, backhand exercise, forehand exercise, ball throwing with racket and control exercise, service exercise to specific area were done. Children in control group participated the programme that include ball throwing on a wall, hit to ball with foot, hitting the ball with the cuff, jogging, running. In order to find out whether the reaction time has improved, all individuals were subjected to a reaction test before and after at the end of 12 weeks. As a result of this study, it was determined that the reaction times of children with Down's syndrome participating in table tennis study were better than children with Down's syndrome who were control group.
\end{abstract}

Keywords Down Syndrome, Table Tennis, Reaction, Exercise

\section{Introduction}

Down syndrome results from trisomy of chromosome 21 . The most common symptom of Down syndrome is mental retardation [1]. In our society, the way of inactive life is very common for individuals with mentally disabled. For this reason, individuals with Down syndrome have a low participation in physical activity because of articulation problem, mental retardation, pulmonary problem (obstruction, insufficient pulmonary circulation), causing them to live an inactive life $[2,3]$. The result of inactivity, in children with Down syndrome faces to obesity, slower reaction time and instable postural control. If we want mental disabled people to live a more active and healthy life, we should encourage them to do sports and provide support. The disabled people's active participation in the sport by getting out of their home life will make them more active individuals within the society [24]. Sharing of same environment together with the individuals with Down's syndrome and healthy individuals will provide them to live a more active and creative life in their daily lives [6]

It should be emphasized that the sportive activities have some kind of rehabilitation effect on people with or without mental disabilities [6]. Participation in well-planned sporting events affect improving balance, muscle strength, function of respiratory and circulatory systems $[25,26]$ When it's considered the positive effects of sports on individuals with disabilities, working activities should be prepared according to their age, abilities and information to meet the sporting needs of people with or without cognitive impairments $[9,13]$. Individuals with Down's syndrome generally have a more sedentary social life. The study of table tennis is an important sport in terms of the more active individuals with Down's syndrome. In addition, the training given by the trainer will be important for these individuals to be more disciplined. Reaction time refers to that assess with the application time or individual's muscle response to stimulation or exercise [2]. However, it is stated that the reaction time is improved by sportive studies $[3,7]$. Because the table tennis is a sporting activity that needs to be played faster, the ability to quickly detect and respond. Meeting the ball of the opponent side and throwbacking made takes place in a matter of seconds. Therefore, the reaction time of the individual must be as soon as possible [5].

In individuals with Down syndrome have insufficient motor skills. Individuals who do not participate in physical activities or are not included in the games by their peers are reported to have progressively poor physical and motor skills [11]. Working of table tennis is a sport with fun and includes games for disabled people. It is aimed to increase 
the behaviour patterns and cognitive skills of individuals with Down's syndrome by means of playing game [12]. One of the issues that scientists have been most interested in since the mid-19th century is the time of reaction [17]. The reaction time is also described as the preparation period required for the movement to occur by taking the stimulus [4, 22]. Some scientists have described the definition of reaction time as the internal timing between taking the stimulus and the answer [23] The movement time is the time from the beginning of the movement to the end of the movement immediately after the reaction time [15]. People with Down's syndrome are generally engaged in swimming sports. Apart from swimming, they rarely deal with different sport branches [21] The purpose of this study is to determine the effect of table tennis sport on the reaction time of disabled people with Down syndrome.

\section{Method}

In this study, the effect of table tennis activity, which lasted for 12 weeks, on the reaction times of individuals with Down syndrome, aged 12-15 years was examined. Twenty individuals with Down syndrome participated in the project "Every child succeeds if you give a chance" that the governor of Malatya started to work. All families provided their informed consent before the study was initiated. A total of ten participants with Down syndrome, 6 boys and 4 girls, voluntarily participated in the exercise group with the permission of their parents. In order to better understand the effect of the work on the reaction time, a control group consisted of 10 individuals with Down's syndrome. Children in control group participated the programme that include ball throwing on a wall, hit to ball with foot, hitting the ball with the cuff, jogging, running. Age, weight and height measurements of all the participants were taken twice before and after the study. The work of table tennis and control group has been made three days a week on Tuesdays, Thursdays and Saturdays for 90 minutes. The work of control group has been included the first $10 \mathrm{~min}$ general warm-up movements followed by the $15 \mathrm{~min}$ ball throwing on a wall, $15 \mathrm{~min}$ hit to ball with foot, 15 min hitting the ball with the cuff, 15 min jogging, 10 min running and 10 min recovery exercises. The work of table tennis for experimental group has been included the first $10 \mathrm{~min}$ general warm-up movements followed by the $70 \mathrm{~min}$ table tennis practice last $10 \mathrm{~min}$ recovery exercises. Each individual worked with his own racket for 12 weeks and a total of 5 table tennis coaches worked in this process. In addition, the trainers gave behavioural training to people with Down's syndrome in order to make their work more productive (The way of speaking, the appealing, getting permission, getting the right to speak, etc.) Weekly work is done as follows;

1. Week: Explanation of game rules and basic posture movements.
2. Week: Display of gripping techniques (ForehandBackhand).

3. Week: Moving study of forehand and backhand techniques.

4. Week: Servicing techniques.

5. Week: Service reception techniques.

6. Week: Serving in a specific area.

7. Week: Body position at the moment of shooting.

8. Week: At the moment of reception, the position of the body and the distance to the table

9. Week: Posture position in pairs.

10. Week: Shooting techniques in pairs.

11. and 12.Weeks: Applying game rules in the competition.

In this study, reaction times were measured before and after the 12-week with Reaction Time Hubbard-Hap brand reaction measuring device for experimental and control group. The measurements were made with the hands used by playing table tennis by individuals participating in the table tennis activity otherwise hands used by the control group in daily life. This test repeated three times and better score recorded.

\section{Data Analyses}

Analysis of the data was made in SPSS 23 statistical package program. Differences between groups were determined by independent sample t-test. In the power analysis performed, assuming that the difference between pre-treatment and post-treatment was 1 unit with $\alpha=0.05$ and $1-\beta$ (power) $=0.80$, at least 18 patients were required for the sample. The Mann-Whitney U test was used for the comparison of the significance of data that did not meet parametric conditions. A value of $p<0.05$ was accepted as statistically significant. Significance was accepted as $p$ $<0.01$ and $\mathrm{p}<0.05$.

\section{Results}

A total of twenty in children with Down syndrome (n:10 experimental group, $\mathrm{n}: 10$ control group) participated in this study. The mean age of the participants was $13.60 \pm 0.84$ years (range $12-15$ years)

Clinical characteristic of the participants are shown in Table 1, There is no significant difference between the age, weight and height of the experimental and control groups $(\mathrm{p}>0.05$

Table 2 shows the pre-test and post-test scores of the experimental group in the table tennis activity and the control group. Regarding the total scores between the applications, statistically significant differences were observed $(\mathrm{p}>0.05)$. 
Table 1. Characteristics of Experimental and Control Group Individuals with Down Syndrome.

\begin{tabular}{|c|c|c|c|c|}
\hline \multicolumn{2}{|c|}{ Group } & n & x & sd \\
\hline \multirow{4}{*}{ Control Group } & Age & 10 & 13,60 years & 1,26 \\
\cline { 2 - 5 } & Weight & 10 & $42,60 \mathrm{~kg}$ & 6,01 \\
\cline { 2 - 5 } & Height & 10 & $150,90 \mathrm{~cm}$ & 4,98 \\
\hline \multirow{3}{*}{$\begin{array}{c}\text { Experimental } \\
\text { Group }\end{array}$} & Age & 10 & 12,59 years & 0,84 \\
\cline { 2 - 5 } & Weight & 10 & $46,00 \mathrm{~kg}$ & 7,19 \\
\cline { 2 - 5 } & Height & 10 & $156,90 \mathrm{~cm}$ & 7,59 \\
\hline \multirow{4}{*}{ Total } & Age & 10 & 13,60 years & 0,84 \\
\cline { 2 - 5 } & Weight & 10 & $46,00 \mathrm{~kg}$ & 7,19 \\
\cline { 2 - 5 } & Height & 10 & $156,90 \mathrm{~cm}$ & 7,59 \\
\hline
\end{tabular}

In Table 3, pre-test comparisons of the reaction times of the experimental group participating in the activity of table tennis and the individuals with Down's syndrome in the control group were made. The average of reaction time of individuals in the experimental group was lower than the average of reaction time of the control group individuals. A statistically significant difference was found $(\mathrm{p}<0.05)$.

Table 2. Normality test for Dependent Variables One-Sample Kolmogorov-Smirnov Test

\begin{tabular}{|c|c|c|c|c|}
\hline & \multicolumn{2}{|c|}{$\begin{array}{c}\text { Experimental } \\
\text { Group }\end{array}$} & \multicolumn{2}{c|}{ Control Group } \\
\hline & Pre-test & Post-test & Pre- test & Post-test \\
\hline & 10 & 10 & 10 & 10 \\
\hline $\mathrm{x}$ & 68,0000 & 55,4000 & 86,6000 & 82,4000 \\
\hline $\mathrm{sd}$ & 16,46545 & 14,62266 & 6,04060 & 6,73448 \\
\hline $\begin{array}{c}\text { Kolmogorov-Smirnov } \\
\text { Test }\end{array}$ &, 219 &, 222 &, 192 &, 182 \\
\hline $\mathrm{p}$ & 0,192 & 0,178 & 0,200 & 0,200 \\
\hline
\end{tabular}

Table 3. Pre-Test Comparison of Reaction Times for Individuals with Down syndrome in the Experimental and Control Groups

\begin{tabular}{|c|c|c|c|c|c|c|c|}
\hline & Group & N & x & ss & Independent T-testi & Sd. & p \\
\hline \multirow{2}{*}{ Pre test } & Experimental Group & 10 & 68,00 & 16,46 & \multirow{2}{*}{18,354} & \multirow{2}{*}{$0,004 *$} \\
\cline { 2 - 8 } & Control Group & 10 & 86,60 & 6,04 & $-3,34$ & & \\
\hline
\end{tabular}

In Table 4, the reaction times of the experimental group were compared with pre-test and post-test. A statistically significant difference was found between the pre-test and post-test of the individuals in the experimental group $(\mathrm{p}<0.01)$.

Table 4. Comparison of Pre-Test and Post-Test of Experiment Group Reaction Times

\begin{tabular}{|c|c|c|c|c|c|c|}
\hline & $\mathbf{x}$ & $\mathbf{N}$ & ss & $\begin{array}{c}\text { Depended Groups } \\
\text { T-test }\end{array}$ & Sd. & p \\
\hline Pre test & 68,00 & 10 & 16,46 & 5,816 & 9 & $0,000^{*}$ \\
\hline Post test & 55,40 & 10 & 14,62 & 9 \\
\hline
\end{tabular}

In Table 5, the reaction times of the control group were compared with pre-test and post-test. No statistically significant difference was observed between the pre-test and post-test of the control group ( $\mathrm{p}>0.01$ ).

Table 5. Comparison of Pre-Test and Post-Test of the Control Group Reaction Times

\begin{tabular}{|c|c|c|c|c|c|c|}
\hline & $\mathbf{x}$ & $\mathbf{N}$ & ss & $\begin{array}{c}\text { Dependent Groups } \\
\text { T-test }\end{array}$ & Sd. & p \\
\hline Pre test & 86,60 & 10 & 6,04 & $-2,905$ & 9 & 0,017 \\
\hline Post test & 82,40 & 10 & 6,73 & 9 \\
\hline
\end{tabular}

In Table 5, the reaction times of the control group were compared with pre-test and post-test. No statistically significant difference was observed between the pre-test and post-test of the control group ( $\mathrm{p}>0.01)$.

Table 6. Post-Test Comparison of Reaction Times for Individuals with Down syndrome in the Experimental and Control Groups

\begin{tabular}{|c|c|c|c|c|c|c|c|}
\hline & Group & N & $\mathbf{x}$ & ss & Independent T-test & Sd. & p \\
\hline \multirow{2}{*}{ Post test } & Experimental Group & 10 & 55,40 & 14,62 & \multirow{2}{*}{$-6,500$} & 18 & $0,000^{*}$ \\
\cline { 2 - 8 } & Control Group & 10 & 82,40 & 6,73 & & \\
\hline
\end{tabular}




\section{Discussion}

This study investigated the effect of table tennis sport on the reaction time of disabled people with Down syndrome. It was found that that the reaction times of individuals with Down's syndrome who have participated in the table tennis activity have decreased. This is the first study to compare the effect of table tennis sport on the reaction time of disabled people with Down syndrome.

The development of motor skills in individuals with Down's syndrome differs from that in non-disabled individuals. The motor skills and development of these individuals are markedly slower. Özdemir et al. [20] have indicated that the inability of individuals with mental disabilities to participate in physical activity adequately would lead to an inactive lifestyle [20] When we look at the work done, it seems that there is no training program for individuals with Down's syndrome. However, there are studies to determine the physiological and motoric properties of individual ls with Down's syndrome [10,14]. Aggon et al [1] point out that 12 -week table tennis training practices significantly improved hand and foot reaction times in the study titled "The effect of table tennis basic training on flexibility and reaction times" [1] This study is similar to the study of Aggon et al [1] in this sense Bompa [8] notes that one of the most important features of improving reaction time is the reaction to a moving subject, and at the same time, he also notes importance of attention [8] The table tennis game is a play based on considerable consideration due to the game feature. When we think that motor skills and reflexes of disabled people with Down's syndrome are very lower, a game based on consideration such as table tennis will make an important contribution to the development of reactions of these individuals. As a result of attention to the individuals with Down's syndrome in this study that continues to table tennis training shows that the reaction times change positively (Table 4 ). When statistical results were examined, a significant difference was found between the test group and the pre-test results of the control group. (Table 3). In this case, we can deduce that the individuals who have participated in table-tennis activity are volunteering and more willing. When the last tests between experimental group and control group were examined, statistically significant difference was found. (Table 6). Regular training or sporting activities affect positively some behavioural changes and motor development in individuals with mentally disabled $[12,23]$. Un and Bahçeci [18] stated that the reaction times of the individuals with mentally disabled who sport are shorter than those who do not [20]. Özdemir et al. [19] concluded that participation in sports activities had a positive effect on physical development, motor development and reaction times of disabled people [19]. The difference between the pre-test and post-test averages of the experimental group we studied is significantly higher than the difference between the control group averages (reaction time is shorter) this shows the effect of attention and concentration studies (Table 2). There was no statistically significant difference in the pre-test and post-test reaction times of individuals with Down's syndrome that we did not study and considered as only control group (Table 5) $(\mathrm{p}>0.05)$.

\section{Conclusions}

As a result, this study found that participated in the table tennis activity reduced the reaction time of children with Down syndrome. Activities target a specific area in the brain that is usually responsible for decreased of reaction time. Shortly, the reaction times of individuals with Down's syndrome who have participated in the table tennis activity have improved, so that the effectiveness of the event has a positive effect on the reaction time of individuals with Down's syndrome.

\section{REFERENCES}

[1] Ağgön E, Ağırbaş Ö, Yazııı M, Uçan İ,(2014)12 Haftalık Masa Tenisi Temel Eğitim Uygulamalarının Esneklik Ve Reaksiyon Zamanları Üzerine Etkisi, Beden Eğitimi ve Spor Bilimleri Dergisi, cilt 16,say1 4,24

[2] Alpkaya U. Çoknaz H.(2002). Reaksiyon Zamanını Etkileyen Faktörler, Spor Araştırmaları Dergisi, 6 (1), 109-121.

[3] Akgün N. (1992). Egzersiz Fizyolojisi. 1. Cilt, Ege Üniversitesi Basımevi, 4. Baskı, 78.

[4] Anson JG. (1989). Effect of Inertia on Simple Reaction Time. Journal of Mot. Behaviour, 60-71.

[5] Baltac1 G. Tunay VB. Tuncer A. Ergun N.(2003). Spor Yaralanmalarında Egzersiz Tedavisi, Alp Yayınevi, 13-14.

[6] Beasley, C. R. (1982). Effects of a jogging program on cardiovascular fitness and work performance of mentally retarded adults. American Journal of Mental Deficiency, 86(6):609-613.

[7] Bompa, T. O. (1998). Antrenman Kurami ve Yöntemi. (Çev; İ Keskin, AB.Taner) Bă̆ırgan Yayınevi, 369-443.

[8] Bompa, T. O. (1990). The Oryand Methodology of Training. Second ed. Dubuque, lowa, Kendall Hunt Publishing Co., $316-328$

[9] Bruininks, R. H., \& Chvat, M. (1990). Research on the motor proficiency of persons with mental retardation. In Psychomotor therapy and adapted physical activity (Ed: HV Coppenolle and J. Simons) In Better Movement Proceeding of the 2nd International Symposium. Belgium, 43-69.

[10] Chasey, W. C., \& Wyrick, W. (1971). Effects of a physical developmental program on psychomotor ability of retarded children. American journal of mental deficiency, 75, 566-570.

[11] Clarke, H. H., \& Clarke, D. H. (1978). Developmental and 
adapted physical education. Second Edition. Prentice Hall, Inc. Englewoad Cliffs, Newjersey.

[12] Dörger, D. (2001). Özürlüler ile Yaratıcı Drama. Ankara: Hacettepe Üniversitesi Aile Hizmetleri ve Uygulama Merkezi (AHUM) Etkinliği, 28.

[13] Eichsteadt CB, Lavay BW. (1992) Adapted Physical Education İn Mental Disabled Children. Human Kinetics Books, 463.

[14] Gençöz, F. (1997). The effects of basketball training on the maladaptive behaviors of trainable mentally retarded children. Research in developmental disabilities, 18(1), $1-10$.

[15] Groves, R. (1973). Relationship of reaction time and movement time in a gross motor skill. Perceptual and motor skills, 36(2), 453-454.

[16] Gürses N. (2007) Engelli Çocuklarda Fiziksel aktivite. Fiziksel Aktiviteyi Engelleyen Kardiyopulmoner Durumlar. Özürlüler'07 Kongresi ve Sosyal Etkinlikleri, Kongre Bildiri Kitabı.İstanbul, 64-69.

[17] Kosinkski JA. (2010). Literatur Review on Reaction time. Clemson University. 006 ; http://biae.clemson.edu/bpc/bp/Lab/11 0/reaction.htm.

[18] Ün, N., Erbahçeci, F., Ergun, N., Tedavi, H. Ü. F., \& YO, R. (2001). Mental retarde çocuklarda fiziksel uygunluğun değerlendirilmesi. Romatizma, 16(1), 16-21.
[19] Özdemir, M., Tanır, H., Ilkım, M., \& Özmaden, M. (2017). The effects of 8 week exercise program on reaction time performance of hearing impaired students at 11-14 years of age. In SHS Web of Conferences (Vol. 37, p. 01031). EDP Sciences.

[20] Özdemir, M., Ilkım, M., \& Tanır, H. (2018). The Effect of Physical Activity On Social Adaptation And Skills Development In Mentally Disabled Individuals. European Journal of Physical Education and Sport Science, 4 (1).

[21] Özdemir M. Kaldırımcı M. Ilkım M. Dinçer N. Mızrak O. (2014) 8 Hafta Süren Fiziksel Egzersizin 11-14 Yaş Aralığındaki Down Sendromlu Özel Öğretim Öğrencilerinin Reaksiyon Zamanları Üzerine Etkisi, Erzurum Beden Eğitimi ve Spor Bilimleri Dergisi,16 (4).

[22] Rosenbaum, D. A. (1991). Human Motor Control Psyiological Foundations Academic Pres. London.

[23] Sullivan, S. J., \& Hayes, K. C. (1987). Changes in short and long latency stretch reflexes prior to movement initiation. Brain research, 412 (1), 139-143.

[24] T.C. Sağlık Bakanlığı Türkiye Halk Sağlığı Kurumu (2014) Engellilerde Fiziksel aktivite, 47.

[25] Winnick J P, Craft D H, Kelly L E. (1990) Adapted Physical Education and Sport. Champaign; 487.

[26] Winnick JP, Nad S. (1985) Physical Fitness Testing of the Disabled. (Project Unique), 18-19. 